\title{
METODE JARITMATIKA UNTUK MELATIH KEMAMPUAN BERHITUNG PENJUMLAHAN DAN PENGURANGAN PESERTA DIDIK KELAS 2 SD
}

\author{
Dzurriyatin Thoyyibah \\ Universitas Nahdlatul Ulama (UNISNU) Jepara \\ diyajeng4@gmail.com
}

\begin{abstract}
Students' numeracy skills must be built from an early age, especially in elementary level learning because it is the basis or foundation in the development of learning. However, in reality the ability of students to count is still relatively low, especially the addition and subtraction material for low-grade students. This is due to the stigma of students who think that learning mathematics is difficult and boring because most teachers are still doing conventional learning in mathematics learning. The jaritmatika method is considered effective in dealing with these problems because the jaritmatika method is a method of counting that uses the help of fingers and involves students directly. This research uses the literature study method or also known as documentation study, the data collection by the author is by collecting as much information as possible from various sources of literature or documentation related to the application of the jaritmatika method in mathematics learning addition and subtraction material. The results of this study indicate that the jaritmatika method can be used to train the addition and subtraction of students' numeracy skills because learning with the jaritmatika method is packaged in a fun way in the form of a game which will greatly influence the development of students. In addition, the method does not burden the brain because it does not need to memorize. With a pleasant situation students will not feel pressured so that students' numeracy skills can increase.
\end{abstract}

Keywords : Jaritmatika Method, Addition and Subtraction, Nomeracy Skills

\begin{abstract}
ABSTRAK
Kemampuan berhitung peserta didik harus dibangun sejak dini terutama dalam pembelajaran tingkat dasar karena merupakan dasar atau fondasi dalam pengembangan pembelajaran. Namun, realitanya kemampuan peserta didik dalam berhitung masih terbilang rendah terutama materi penjumlahan dan pengurangan pada peserta didik kelas rendah. Hal ini disebabkan oleh stigma peserta didik yang menganggap bahwa pembelajaran matematika itu susah, dan membosankan karena kebanyakan guru masih melakukan pebelajaran konvensional pada pembelajaran matematika. Metode jaritmatika dianggap efektif untuk menangani permasalahan tersebut karena metode jaritmatika ialah metode berhitung yang menggunakan bantuan jari-jari tangan dan melibatkan peserta didik secara langsung. Penelitian ini menggunakan metode studi kepustakaan atau disebut juga studi dokumentasi, pengumpulan data yang dilakukan penulis adalah dengan cara mengumpulkan informasi sebanyakbanyaknya dari berbagai sumber kepustakaan atau dokumentasi yang berhubungan dengan penerapan metode jaritmatika dalam pembelajaran matematika materi penjumlahan dan pengurangan. Hasil penelitian ini menunjukkan bahwa metode jaritmatika dapat digunakan untuk melatih kemampuan berhitung penjumlahan dan pengurangan peserta didik karena pembelajaran dengan metode jaritmatika dikemas secara menyenangkan dalam bentuk permainan yang akan sangat berpengaruh bagi perkembangan peserta didik. Selain itu, metode jaritmatika tidak memberatkan otak karena tidak perlu menghafal. Dengan situasi yang menyenangkan peserta didik tidak akan merasa tertekan sehingga kemampuan berhitung peserta didik dapat meningkat.
\end{abstract}

Kata Kunci: Metode Jaritmatika, Penjumlahan dan Pengurangan, Kemampuan Berhitung 


\section{Dzurriyatin Thoyyibah : Metode Jarimatika Untuk Melatih Kemampuan Berhitung Penjumlahan dan Pengurangan Peserta Didik Kelas 2 SD}

\section{Pendahuluan}

Matematika merupakan ilmu dasar yang memiliki peran penting dalam dunia pendidikan dan termasuk salah satu ilmu yang mendasari pesatnya perkembangan teknologi dan pengetahuan masa kini. Mata pelajaran matematika wajib diberikan bagi semua peserta didik tingkat sekolah dasar guna membekali peserta didik kemampuan berfikir logis, kritis, analitis, sistematis dan dapat membentuk peserta didik berpikir secara ilmiah. Selvianiresa (2017) menyebutkan bahwa pembelajaran matematika bukan hanya berorientasi pada kemampuan berfikir kognitif peserta didik saja, namun juga berorientasi pada keterampilan peserta didik dalam pemecahan masalah yang bersifat abstrak dan disajikan dengan simbol-simbol matematika. Oleh sebab itulah matematika sering dianggap sebagai pelajaran yang 'menakutkan', membosankan, membingungkan dan dihindari oleh peserta didik. Apalagi masih banyak para guru yang menggunakan model konvensional hanya dengan ceramah, menghafal dan mengingat pelajaran tanpa didukung dengan media pembelajaran atau model pembelajaran yang inovatif dan melibatkan peserta didik agar aktif dalam pembelajaran. Selain itu, adanya stigma turun-temurun yang menyatakan bahwa matematika itu pelajaran yang sulit secara tidak langsung sudah menurunkan motivasi belajar peserta didik terutama peserta didik kelas rendah.

Peserta didik kelas rendah terutama kelas II SD masih sering merasa kesulitan untuk mengoperasionalkan penjumlahan dan pengurangan. Metode monoton yang disajikan oleh guru sangat tidak sesuai dengan karakteristik peserta didik kelas rendah yang masih suka bermain dan banyak bergerak. Selain itu, penerapan metode yang 'kliru' oleh guru akan membuat peserta didik tidak tertarik untuk mengikuti pembelajaran. Padahal jika ditilik lebih dalam materi penjumlahan dan pengurangan merupakan materi dasar yang harus dikuasai oleh peserta didik jika ingin menguasai materi selanjutnya yang lebih kompleks. Materi penjumlahan dan pengurangan dengan teknik menyimpan juga menjadi beban tersendiri bagi peserta didik. penanaman konsep yang salah serta pembelajaran tanpa penggunaan media akan membuat peserta didik kesulitan untuk meng-'abstrak'nya apalagi peserta didik kelas rendah masih berada pada tahap operasional konkret yang membutuhkan media nyata untuk mengkontruksi pengetahuannya. 


\section{Dzurriyatin Thoyyibah : Metode Jarimatika Untuk Melatih Kemampuan Berhitung Penjumlahan dan Pengurangan Peserta Didik Kelas 2 SD}

Menurut Pitadjeng (2015) belajar matematika akan lebih efektif apabila pembelajaran tersebut dikemas dalam suasana yang menyenangkan. Suasana menyenangkan yang dihadirkan oleh guru setiap harinya akan menambah motivasi belajar peserta didik sehingga peserta didik tidak akan merasa tertekan dalam mengikuti pembelajaran dan akan menganggap matematika sebagai mata pelajaran yang asik dan menarik. Selaras dengan hal tersebut, Heruman (2014) menyatakan bahwa dalam pembelajaran matematika, setiap konsep abstrak yang baru dipahami oleh peserta didik perlu segera diberi penguatan, agar dapat membekas bagi ingatan peserta didik. Salah satu cara penguatan yang dapat dilakukan ialah dengan metode learning by doing atau belajar sambil melakukan, atau bisa juga dikemas dalam bentuk belajar sambil bermain yang disesuaikan dengan karakteristik peserta didik tingkat SD kelas rendah.

Metode jaritmatika merupakan metode yang dianggap efektif untuk menangani permasalahan tersebut karena metode jaritmatika ialah metode berhitung yang menggunakan bantuan jari-jari tangan. Keterlibatan peserta didik untuk menggunakan metode jaritmatika dalam berhitung akan menjadikan pembelajaran lebih bermakna dan menyenangkan. Penggunaan metode jaritmatika dapat memberikan visualisasi proses berhitung dan dapat dilakukan dengan mudah oleh peserta didik. Metode jaritmatika juga mampu mengembangkan gaya belajar peserta didik baik gaya belajar visual, auditori, maupun kinestetik dimana peserta didik dapat belajar berhitung sambil bernyanyi dan memainkan jari mereka. Dengan penerapan metode jaritmatika ini maka pembelajaran akan terasa lebih menyenangkan dan peserta didik dapat terlibat aktif dalam pembelajaran.

Bertolak dari beberapa pemikiran yang telah dijabarkan di atas, maka penelitian ini dirumuskan dalam judul "Metode Jaritmatika Untuk Melatih Kemampuan Berhitung Penjumlahan Dan Pengurangan Peserta Didik Kelas 2 SD". Dengan perumusan tersebut maka tujuan dari penelitian ini adalah: 1) Untuk mengidentifikasi peran metode jaritmatika dalam melatih kemampuan berhitung penjumlahan dan pengurangan peserta didik kelas 2 SD, dan 2) Untuk menganalisis kelebihan metode jaritmatika dalam melatih kemampuan berhitung penjumlahan dan pengurangan peserta didik kelas 2 SD.

\section{Metode Penelitian}




\section{Dzurriyatin Thoyyibah : Metode Jarimatika Untuk Melatih Kemampuan Berhitung Penjumlahan dan Pengurangan Peserta Didik Kelas 2 SD}

Metode yang digunakan dalam penelitian ini adalah metode penelitian kepustakaan atau studi dokumentasi, karena pada penelitian ini peneliti hanya menggunakan sumber perpustakaan dan dokumentasi untuk memperoleh data (Zed, 2014). Teknik pengumpulan data yang dilakukan adalah dengan cara mengumpulkan informasi sebanyak-banyaknya dari berbagai sumber kepustakaan atau dokumentasi yang berhubungan dengan penerapan metode jaritmatika dalam pembelajaran matematika materi penjumlahan dan pengurangan. Sumber kepustakaan yang digunakan dalam penelitian ini diperoleh dari buku, jurnal, hasilhasil penelitian (tesis dan disertasi), serta sumber lainnya seperti kebijakan pemerintah dan kurikulum.

Dalam penelitian kepustakaan atau studi dokumentasi, seorang peneliti wajib mengikuti kaidah-kaidah yang berlaku. Antara lain adalah mengidentifikasikan teori secara sistematis, penemuan pustaka, serta analisis dokumen berisi informasi yang berkaitan dengan topik penelitian. Sehingga, setelah bahan kepustakaan terkumpul, peneliti dapat menyusun bahan tersebut secara sistematis dan mengklasifikasikannya sebagai data relevan dan tidak relevan. Kemudian, pada akhir tahapan peneliti melakukan analisis terhadap teori-teori yang didapatkan.

\section{Hasil dan Pembahasan}

\section{Metode Jaritmatika}

Metode jaritmatika merupakan suatu metode belajar menghitung dalam matematika yang digagas oleh Ibu Septi Peni Wulandari. Menurut Wulandari (2013) metode jaritmatika adalah suatu cara yang digunakan untuk melatih kemampuan berhitung (Kali Bagi Tambah dan Kurang atau biasa disebut KABATAKU) dengan menggunakan jari-jari. Sulistyaningsih (2018) menyebutkan bahwa jaritmatika merupakan suatu metode dalam pembelajaran matematika (khususnya berhitung) yang menyenangkan dengan menggunakan sepuluh jari tangan. Metode jaritmatika dianggap menyenangkan karena anak turut terlibat secara langsung menggunakan jari-jari mereka sendiri. Penerapan metode jaritmatika ini harus dibekali oleh penanaman konsep dasar yang benar seperti konsep bilangan, lambang bilangan dan operasi hitung dasar. Selain itu, Astuti (2013) menyebutkan bahwa metode jaritmatika adalah metode berhitung yang 
sangat cocok diterapkan untuk peserta didik usia operasional konkret, dimana jari-jari tangan anak berfungsi sebagai objek nyata dan simbol numerik.

Menurut Asih (2009) metode jaritmatika adalah alternatif jitu untuk mengatasi kesulitan menghitung peserta didik. Pembelajaran dengan metode jaritmatika adalah pembelajaran yang dikemas dalam bentuk permainan yang akan sangat berpengaruh bagi perkembangan peserta didik. Melalui permainan peserta didik dapat menemukan kekuatan serta kelemahannya sendiri, dapat mengenali minatnya dan juga dapat menemukan cara-cara untuk menyelesaikan tugas dan melatih konsentrasi. Pembelajaran dengan metode jaritmatika juga dianggap ideal karena dapat melibatkan emosi, seluruh tubuh dan semua panca indera.

Dari beberapa pendapat tersebut dapat disimpulkan bahwa metode jaritmatika merupakan metode yang memudahkan peserta didik untuk belajar berhitung dengan bantuan jari-jari mereka dan dapat mengemas pembelajaran menjadi menyenangkan karena peserta didik turut terlibat secara langsung menggunakan jari-jari mereka sendiri.

\section{Langkah Pengaplikasian Metode Jaritmatika dalam Operasi Penjumlahan} dan Pengurangan

Kunci keberhasilan penerapan metode jaritmatika di SD adalah adanya pengulangan terus-menerus dan penanaman konsep yang 'satu' serta benar. Adapun langkah penerapan metode jaritmatika menurut Wulandari (2013) adalah:

\section{a. Perkenalan}

Tahap perkenalan ini adalah tahap yang dilakukan dengan cara mengenalkan peserta didik terhadap lambang-lambang bilangan yang digunakan dalam jaritmatika. Dimulai dengan tangan kanan sebagai lambang bilangan satuan mulai dari 1 sampai 9 seperti gambar di bawah ini 


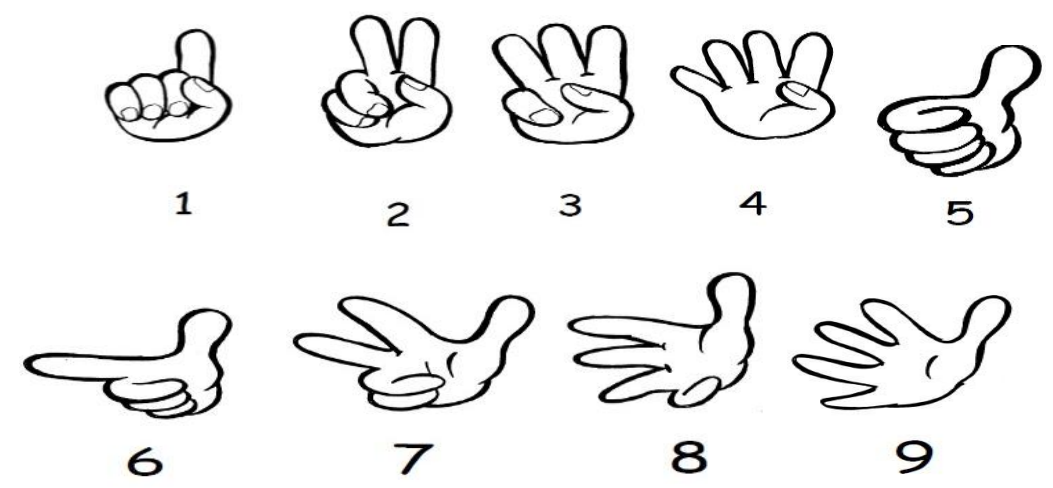

Dilanjutkan dengan pengenalan tangan kiri sebagai lambang bilangan 10 sampai 90 seperti gambar di bawah ini
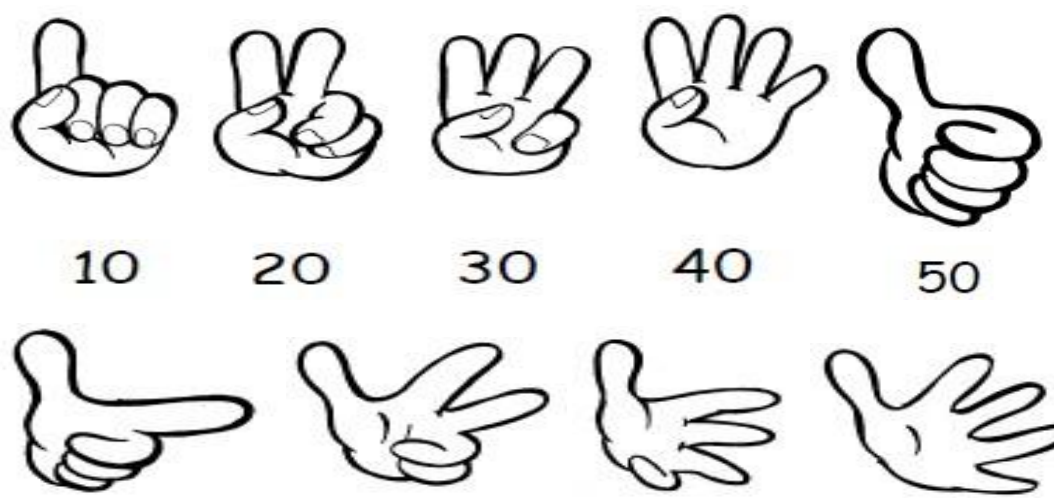

50
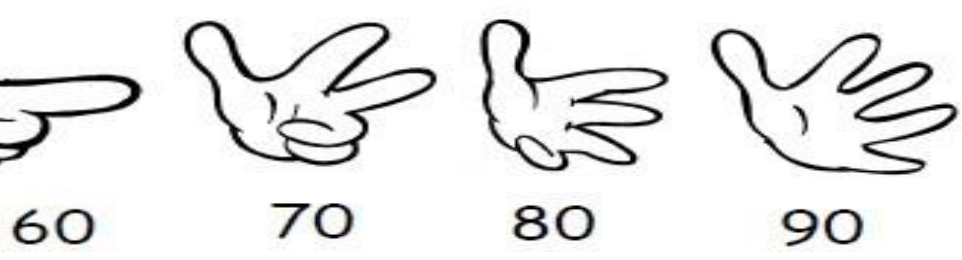

80

90

Contoh :

Lambang bilangan 27 dalam jaritmatika dapat digambarkan sebagai berikut
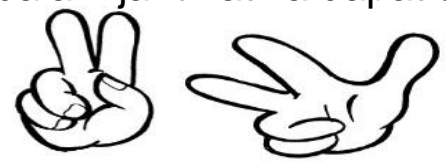

2

7

Dan lambang bilangan 99 dapat digambarkan sebagai berikut

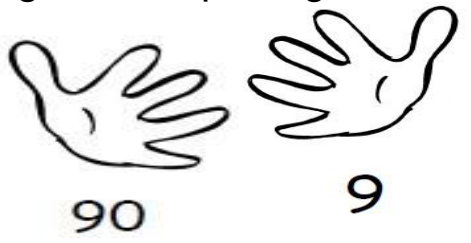

b. Pendalaman praktek operasi penjumlahan dan pengurangan sederhana

Tahap ini dapat dimulai dengan melakukan penjumlahan dan pengurangan sederhana agar peserta didik dapat memahami sepenuhnya. Contoh untuk penjumlahan :

$1+2=$ 
Formasi jaritmatikanya dapat digambarkan sebagai berikut :

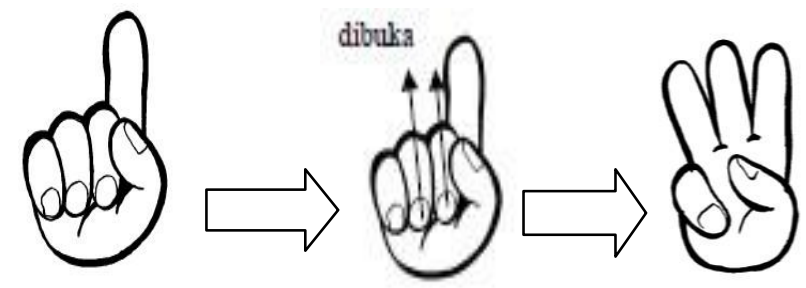

Dibaca : tambah satu BUKA, tambah dua BUKA, oke

Hasilnya adalah : 3

Contoh berikutnya untuk pengurangan :

$3-1=$

Formasi jaritmatikanya dapat digambarkan sebagai berikut :
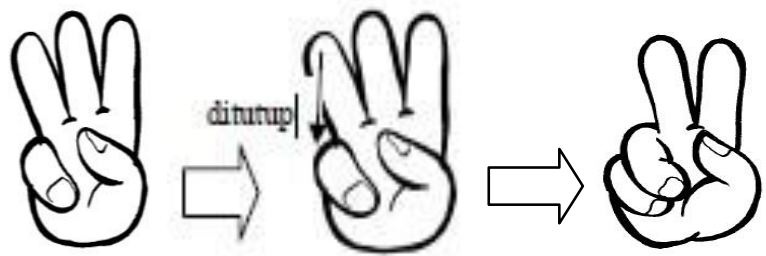

Dibaca : tambah tiga BUKA, kurung satu TUTUP, oke

Hasilnya adalah gambar terakhir yang menunjukkan bilangan 2 .

Hal ini juga berlaku untuk puluhan.

Contoh untuk puluhan

$$
20+10=\ldots .
$$
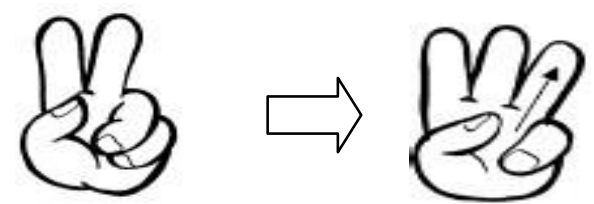

Dibaca: Tambah dua puluh BUKA, tambah sepuluh BUKA, oke Hasilnya, lihat tangan kiri, adalah 30 .

Setelah peserta didik menguasai konsep dasar tersebut, guru dapat melanjutkan pembelajaran dengan mempraktekkan penjumlahan dua angka dan operasi campuran antara penjumlahan dan pengurangan seperti contoh di bawah ini :

1. $21+13-12=$ 


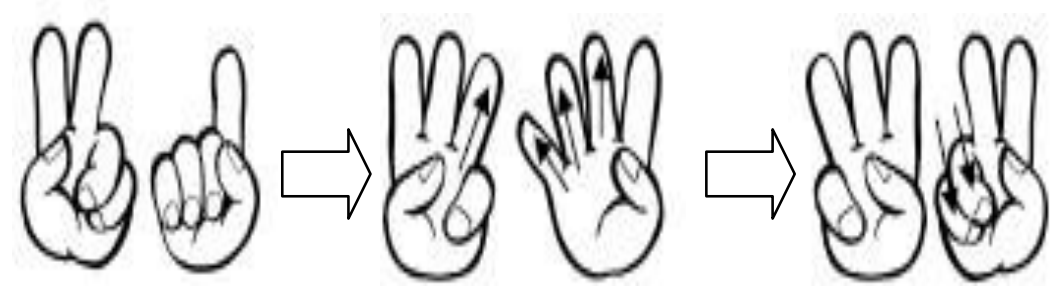

Dibaca: Tambah dua puluh satu BUKA, (tambah tiga belas) tambah sepuluh BUKA, tambah tiga BUKA, kurang dua TUTUP. Dan hasilnya adalah 22.

2. $6-5+3-1=$
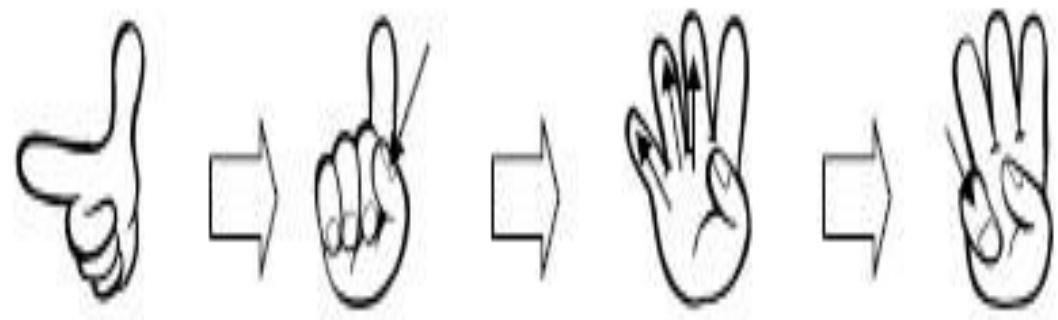

Dibaca:Tambah enam BUKA, kurang lima TUTUP, tambah tiga BUKA, kurang satu TUTUP, oke. Dan hasilnya adalah 3

c. Pendalaman praktek operasi penjumlahan dan pengurangan yang lebih kompleks. Dengan mengenalkan konsep teman kecil, teman besar dan formula gabungan.

\section{Kelebihan Metode Jaritmatika}

Jaritmatika memperkenalkan pada peserta didik bahwa berhitung itu mudah dan menyenangkan. Mudah karena mereka menggunakan jari mereka sendiri dan menyenangkan karena pembelajaran dikemas secara gembira. Dalam proses yang menyenangkan dan penuh kegembiraan itulah peserta didik dibimbing dan dilatih agar dapat berhitung dengan benar dan tidak dalam tekanan (Tribudiyono, 2012). Selain itu, nilai lebih dari metode jaritmatika ini adalah tidak memberatkan memori dan bayangan, melatih konsentrasi serta medianya tersedia dalam tubuh. Wulandari (2013) menyebutkan ada beberapa kelebihan dalam penerapan metode jaritmatika yaitu: a) Memberikan visualisasi proses berhitung pada peserta didik; b) Gerakan jari tangan dapat menarik minat dan motivasi belajar peserta didik, dan c) Tidak memerlukan hafalan yang menjenuhkan. 
Kelebihan lain dari metode jarimatika adalah tidak menghilangkan konsep operasi matematis, tetapi proses berhitung dapat diupayakan lebih mudah dan cepat. Metode ini mungkin bersifat primitive, akan tetapi metode ini mudah diterima dan dipahami oleh peserta didik karena cukup menarik, praktis, sederhana, dan ekonomis, karena hanya mengunakan sepuluh jari tangan. Metode jaritmatika dianggap spesial karena penggunaan metode ini sangat ekonomis dan tidak memerlukan biaya sepeserpun karena medianya hanya jarijari tangan dan konsentrasi serta keuletan guru dan peserta didik. Gerakan jarijari saat menghitung juga dapat melatih aspek psikomotorik peserta didik yang akan berguna bagi tingkat kecakapannya. Metode ini juga dapat mengembangkan kinerja otak kanan dan kiri peserta didik, baik secara motorik maupun secara fungsional sehingga otak bekerja lebih optimal dan terbiasa terarah.

4. Peran Metode Jaritmatika dalam melatih Kemampuan Berhitung Peserta Didik

Pembelajaran di sekolah dasar terutama di kelas rendah selalu mengutamakan pada kemampuan membaca, menulis dan berhitung. Kemampuan berhitung peserta didik harus dibangun sejak dini terutama dalam pembelajaran tingkat dasar karena merupakan fondasi dalam pengembangan pembelajaran. Metode jaritmatika merupakan alternatif jawaban untuk permasalahan tersebut. Metode jaritmatika dianggap efektif untuk melatih kemampuan berhitung anak karena metode jaritmatika berperan sebagai cara atau teknik sekaligus media yang bermanfaat untuk memberikan rasa senang bagi peserta didik dalam proses pembelajaran serta memberi visualisasi peserta didik dalam berhitung (Sitio, 2017).

Metode jarimatika merupakan bentuk pembelajaran yang sangat menarik dan memudahkan peserta didik untuk dapat menyelesaikan tugas-tugas yang diberikan oleh guru. Keadaan yang menarik ini memungkinkan dapat meningkatkan kemampuan berhitung peserta didik, karena dengan ketertarikan peserta didik terhadap metode ini maka peserta didik akan lebih berminat untuk mengikuti pembelajaran matematika. Pembelajaran dengan metode jaritmatika juga dianggap ideal karena dapat melibatkan emosi, seluruh tubuh dan semua 
panca indera. Metode jaritmatika juga termasuk metode yang dianggap efektif untuk menangani permasalahan tersebut karena metode jaritmatika ialah metode berhitung yang menggunakan bantuan jari-jari tangan (Sumirat, 2017).

Keterlibatan peserta didik untuk menggunakan metode jaritmatika dalam berhitung akan menjadikan pembelajaran lebih bermakna dan menyenangkan. Penggunaan metode jaritmatika dapat memberikan visualisasi proses berhitung dan dapat dilakukan dengan mudah oleh peserta didik. Metode jaritmatika juga mampu mengembangkan gaya belajar peserta didik baik gaya belajar visual, auditori, maupun kinestetik dimana peserta didik dapat belajar berhitung sambil bernyanyi dan memainkan jari mereka. Dengan penerapan metode jaritmatika ini maka pembelajaran akan terasa lebih menyenangkan dan peserta didik dapat terlibat aktif dalam pembelajaran.

\section{Metode}

Penelitian ini menggunakan metode studi kepustakaan atau disebut juga studi dokumentasi, pengumpulan data yang dilakukan penulis adalah dengan cara mengumpulkan informasi sebanyak-banyaknya dari berbagai sumber kepustakaan atau dokumentasi yang berhubungan dengan penerapan metode jaritmatika dalam pembelajaran matematika materi penjumlahan dan pengurangan.

\section{Simpulan}

Metode jaritmatika merupakan metode yang memudahkan peserta didik untuk belajar berhitung dengan bantuan jari-jari mereka dan dapat mengemas pembelajaran menjadi menyenangkan karena peserta didik turut terlibat secara langsung menggunakan jari-jari mereka sendiri. Nilai lebih dari metode jaritmatika ini adalah tidak memberatkan memori dan bayangan, melatih konsentrasi serta medianya tersedia dalam tubuh, ekonomis dan juga dapat mengembangkan kinerja otak kanan dan kirinya

Metode jaritmatika juga termasuk metode yang dianggap efektif untuk menangani permasalahan tersebut karena metode jaritmatika ialah metode berhitung yang menggunakan bantuan jari-jari tangan. Keterlibatan peserta didik untuk menggunakan metode jaritmatika dalam berhitung akan menjadikan pembelajaran 
lebih bermakna dan menyenangkan. Penggunaan metode jaritmatika dapat memberikan visualisasi proses berhitung dan dapat dilakukan dengan mudah oleh peserta didik.

\section{DAFTAR PUSTAKA}

Asih, N. M. (2009). Penerapan Metode Jarimatika untuk Meningkatkan Pemahaman Konsep Penjumlahan dan Pengurangan pada Siswa Kelas 1 dan 2 SDN 6 Sesetan, Denpasar Selatan. Jurnal Pendidikan Dan Pembelajaran, 16(1), 1-8. Astuti, T. (2013). Metode Berhitung Lebih Cepat Jaritmatika. Lingkar Media. Heruman. (2014). Model Pembelajaran Matematika di Sekolah Dasar. Rosda Karya. Idham Sumirat, T. W. (2017). Pengaruh Praktik Jarimatika Terhadap Keterampilan Berhitung Perkalian Pada Siswa Kelas li Sd. Jurnal Kreatif : Jurnal Kependidikan Dasar, $7(1)$.

Pitadjeng. (2015). Pembelajaran Matematika yang Menyenangkan. Graha IImu.

Selvianiresa, D. (2017). Kesulitan Siswa Sekolah Dasar Pada Materi Nilai Tempat Mata Pelajaran Matematika di Kelas 1 SD. Jurnal IImiah Pendidikan Dasar, 2(1). Sitio, T. (2017). Penerapan Metode Jarimatika Untuk Meningkatkan Hasil Belajar Matematika Siswa Kelas I SDN 003 Pagaran Tapah Darussalam Kabupaten Rokan Hulu. Jurnal Primary Program Studi Pendidikan Guru Sekolah Dasar Fakultas Keguruan Dan Ilmu Pendidikan Universitas Riau, 6(1).

Sulistyaningsih, N. (2018). Peningkatan Keaktifan Belajar Matematika dengan Metode Jaritmatika. Jurnal Pendidikan: Riset Dan Konseptual, 2(1), 57-63.

Tribudiyono. (2012). Peningkatan Hasil Belajar Matematika dalam Menyelesaikan Soal Bilangan Perkalian dan Pembagian di Kelas II SD dengan Metode Jaritmatika. Jurnal Formatif, 1(3), 255-263.

Wulandari, C. (2013). Pembelajaran berhitung penjumlahan dengan jarimatika. Jurnal Didaktik Matematika, 8(1), 1-11.

Zed, M. (2014). Metode Penelitian Kepustakaan. Yayasan Obor Indonesia. 